\title{
Measured energy value of pistachios in the human diet
}

\author{
David J. Baer*, Sarah K. Gebauer and Janet A. Novotny \\ US Department of Agriculture, Agricultural Research Service, Beltsville Human Nutrition Research Center, \\ Beltsville, MD 20705, USA
}

(Received 29 September 2010 - Revised 7 April 2011 - Accepted 12 April 2011 - First published online 28 June 2011)

\section{Abstract}

Previous studies have suggested that lipid from nuts is more poorly absorbed than that from other food sources. If lipid from nuts is poorly absorbed, then the metabolisable energy contained in the nuts is less than that predicted by the Atwater general factors. A crossover feeding study was conducted in which sixteen volunteers consumed pistachios for 3 weeks as part of a controlled diet. Pistachio doses were 0 , 42 and $84 \mathrm{~g} / \mathrm{d}$. Urine and faecal samples were collected, and urine, faeces and diet were analysed for N, fat, total dietary fibre, ash and combustible energy. Blood was also collected after each treatment period and analysed for plasma lipids. Energy value of pistachio nuts was calculated from differences in energy excretion during the different dietary treatments. The measured energy density of pistachios was found to be $22.6 \mathrm{~kJ} / \mathrm{g}$, which is $5 \%$ less than the currently accepted energy value of $23.7 \mathrm{~kJ} / \mathrm{g}$, as calculated using the Atwater general factors. The pistachio nut intervention lowered LDL-cholesterol by $6 \%$, but did not significantly change plasma total cholesterol, HDL-cholesterol or TAG. In conclusion, pistachio nuts contain less metabolisable energy than that calculated from the Atwater general factors. Accurate information about metabolisable energy content of foods is important for reliable food labelling.

\section{Key words: Nuts: Digestibility: Metabolisable energy}

The epidemic of obesity continues to grow throughout the world $^{(1)}$. Estimates suggest that the direct cost of obesity accounts for approximately $7 \%$ of total health care ${ }^{(2)}$. Lowering dietary energy density has been suggested as an effective strategy to prevent and treat obesity ${ }^{(2-4)}$. More ambitiously, James $^{(5)}$ has proposed a full transformation of the food system to one of nutritious, low-energy-dense foods.

Nuts are considered as an energy-dense food, having an estimated $23-30 \mathrm{~kJ} / \mathrm{g}$ compared with an energy density of $7 \cdot 5 \mathrm{~kJ} / \mathrm{g}$ for a typical diet overall ${ }^{(4)}$. Thus, inclusion of nuts in the diet would be counter to the recommendations to reduce dietary energy density. However, nuts convey various important health benefits. Studies have shown that nuts reduce risk factors associated with CVD in clinical studies ${ }^{(6-8)}$, lower risk factors or incidence of cardiovascular events in epidemiological studies $^{(9,10)}$, reduce glycaemic index of a composite meal ${ }^{(11)}$, lower risk of diabetes ${ }^{(12)}$, improve glucose metabolism $^{(13,14)}$ and possibly lower cancer risk ${ }^{(15,16)}$. Thus, excluding nuts from the diet to lower energy density withholds key health benefits that nuts provide.

Epidemiological studies have suggested that individuals consuming nuts regularly do not suffer from higher body weights or BMI values, but rather there is an inverse association between frequent nut consumption and $\mathrm{BMI}^{(10,17)}$. In addition to epidemiological associations, clinical studies indicate that incorporation of nuts into an otherwise ad libitum diet promotes little to no weight gain ${ }^{(18-23)}$. Clinical studies also indicate that lipid from nuts is poorly absorbed, based on postprandial lipaemia and appearance of fat in faecal samples ${ }^{(24-27)}$. It follows then that nuts impart less dietary energy than the value calculated from the Atwater general factors, though this has never been addressed in a feeding study. This study was conducted to determine the energy value of nuts incorporated into an otherwise balanced diet.

\section{Experimental methods}

\section{Subjects, study design and diet}

A convenience sample of men and women was recruited from the area surrounding the Beltsville Human Nutrition Research Center (Beltsville, MD, USA) to participate in a feeding study. Volunteers were healthy non-smokers with no malabsorption or gastrointestinal disorders and no history of bariatric surgery. This study was conducted according to the guidelines laid down in the Declaration of Helsinki, and all procedures involving human subjects were approved by the MedStar

Abbreviations: FE, faecal energy; GEI, gross energy intake; ME, metabolisable energy; MEI, metabolisable energy intake; UE, urinary energy.

Mention of trade names or commercial products in this publication is solely for the purpose of providing specific information and does not imply recommendation or endorsement by the US Department of Agriculture.

*Corresponding author: D. J. Baer, fax +1 301504 9098, email david.baer@ars.usda.gov 
Health Research Institute Committee on Human Research (Hyattsville, MD, USA). Written informed consent was obtained from all the subjects.

A total of eighteen subjects (nine men, nine women) were selected to participate in a dose-response, randomised crossover controlled feeding trial (all food items weighed to the nearest gram amount). Three doses of pistachios were fed as part of a controlled diet with each dose fed for $18 \mathrm{~d}$. The doses studied were the following: (1) $0 \mathrm{~g} / \mathrm{d}$ (control), (2) $42 \mathrm{~g} / \mathrm{d}$ (equal to one serving per $\mathrm{d}$ as defined by the US Food and Drug Administration) and (3) $84 \mathrm{~g} / \mathrm{d}$ (equal to two servings per $\mathrm{d}$ ). The pistachios were incorporated into a controlled diet with a proportionate reduction of all foods in the controlled diet to maintain isocaloric intake across treatments. Subjects were stratified by sex and initial BMI and randomly assigned to a treatment sequence. Each sequence included two dose levels $(0,1.5$ or $3 \mathrm{oz} / \mathrm{d})$ and a repetition of one of the doses, and the dose sequence was randomly assigned by a statistician.

Study subjects were fed at weight maintenance. Body weight was measured, before breakfast, Monday to Friday, to identify patterns of weight loss or weight gain over 7- to 10-d periods. If patterns of weight change were observed, portion size was adjusted for all foods (in $837 \mathrm{~kJ}$ increments) to maintain weight. No diet adjustments were made during the balance collection periods. Volunteers were fed traditional American foods incorporated into a constant 7-d menu cycle and were instructed to consume all the food and only the food provided by the Beltsville Human Nutrition Research Center. Breakfast and dinner were consumed at the Nutrition Center, and lunch and weekend foods were packed for carry-out. Breakfast and dinner on weekdays, including pistachio treatments, were consumed under the observation of a dietitian, research associate or investigator to verify compliance. Subjects completed questionnaires daily to report any breeches in compliance, and study staff regularly engaged subjects in conversations about compliance. The fat: fibre ratio of the background diet was matched to that of the nuts so that it remained constant over all treatments, since fibre has been shown to influence fat absorption ${ }^{(28)}$.

\section{Biological sample collection and chemical analyses}

Faecal collections were initiated on the 9th day after the treatment began and subjects started consuming diet. To mark the beginning of the faecal collection period, we administered, at dinner, a capsule containing approximately $15 \mathrm{mg}$ brilliant blue. After the subjects consumed the capsule, they were instructed to collect all of their faeces. After $7 \mathrm{~d}$, a second capsule of brilliant blue was administered at dinner, and subjects were instructed to continue collecting their faeces until they were told to stop by a study investigator (once the appearance of the marker in faeces was observed by study staff). The brilliant blue marker was used to determine the beginning and end points of the faecal balance period. Faecal samples were stored in a cooler with dry ice until delivery to the Center, usually within $12 \mathrm{~h}$ of collection. Once received at the Center, faecal samples were weighed (wet weight) and placed in a freezer until they were freeze-dried. Immediately after they were removed from the freeze-drier, the samples were weighed (dry weight), and then pulverised using a food processor to produce a homogeneous powder. Diets were collected and prepared for chemical analysis by homogenising the food in a blender with ice and water before being freeze-dried.

Urine was collected in pre-weighed 4-liter containers with $15 \mathrm{~g}$ boric acid. The containers were kept on ice and delivered to the Center each morning. Each day, subjects received new containers. At the Center, samples were weighed and subsamples were collected and stored at $-80^{\circ} \mathrm{C}$ until analyses were performed. The weight of the urine voided was calculated as the difference between the full container weight and the pre-tare empty container weight.

Diets, faeces and urine were analysed for combustible energy by adiabatic bomb calorimetry (Parr Instrument Company, Moline, IL, USA) and for $\mathrm{N}$ by combustion (Leco, St. Joseph, MI, USA). Diets and faeces also were analysed for fat (petroleum extraction; Foss, Eden Prairie, MN, USA), total dietary fibre (Foss) and ash (muffle furnace). All analyses were carried out in duplicate, and the mean of these values was used for statistical analyses.

Blood samples were collected at the end of each treatment period. Blood was collected from an antecubital vein using an appropriate-sized needle into an evacuated sterile tube containing EDTA. Following collection, the tubes were centrifuged and the plasma was collected, aliquoted and frozen at $-80^{\circ} \mathrm{C}$ until analyses. Plasma total cholesterol, direct LDLcholesterol, HDL-cholesterol and TAG levels were measured using enzymatic photometric methods (Dimension Xpand; Dade-Behring, Deerfield, IL, USA).

\section{Calculations}

Total carbohydrate (DM basis) was calculated as follows:

$$
\text { Total carbohydrate }(\%)=100-(\% \text { fat }+\% \text { protein }+\% \text { ash }) \text {. }
$$

We derived the following equation for the metabolisable energy (ME) value of pistachios from the relationship that the ME of the whole diet is equal to the sum of the ME values of the parts:

$$
\begin{aligned}
\mathrm{ME}_{\text {pistachios }}(\mathrm{kJ})= & \mathrm{MEI}_{\text {base diet plus pistachios }}-\mathrm{GEI}_{\text {pistachios }} \\
& \times(\mathrm{MEI} / \mathrm{GEI})_{\text {base diet }}
\end{aligned}
$$

where GEI is the gross energy intake $(\mathrm{kJ} / \mathrm{d})$ and MEI the ME intake $(\mathrm{kJ} / \mathrm{d})$. MEI is calculated as the difference between GEI and faecal (FE) and urinary energy (UE) output (MEI = GEI - (FE + UE)).

Nutrient digestibility was calculated as follows:

$$
\text { Nutrient or energy digestibility (\%) }
$$

$$
=\left(\frac{\text { intake }- \text { excreted }}{\text { intake }}\right) \times 100 \text {. }
$$


Table 1. Physical characteristics of eight male and eight female subjects who completed the intervention (Mean values and ranges)

\begin{tabular}{lcc}
\hline & Mean & Range \\
\hline Age (years) & 50 & $29-64$ \\
BMl $\left(\mathrm{kg} / \mathrm{m}^{2}\right)$ & 27.9 & $20 \cdot 8-34 \cdot 5$ \\
TAG $(\mathrm{mg} / \mathrm{l})$ & 1000 & $450-1660$ \\
LDL-cholesterol $(\mathrm{mg} / \mathrm{l})$ & 1150 & $800-1830$ \\
HDL-cholesterol $(\mathrm{mg} / \mathrm{l})$ & 540 & $320-780$ \\
Glucose $(\mathrm{mg} / \mathrm{l})$ & 870 & $720-990$ \\
Blood pressure (mmHg) & $120 / 72$ & $98 / 50-140 / 90$ \\
\hline
\end{tabular}

The currently accepted energy value of pistachios, as found on nutrient labels and in the USDA National Nutrient Database for Standard Reference (US Department of Agriculture, Agricultural Research Service, 2009. USDA National Nutrient Database for Standard Reference, Release 22. Nutrient Data Laboratory Home Page, http://www.ars.usda.gov/nutrientdata), is based on the Atwater general factors for the energy density of fat, protein and carbohydrate. The Atwater factors for fat, protein and carbohydrate are $37 \cdot 7,16.7$ and $16.7 \mathrm{~kJ} / \mathrm{g}$ respectively.

$$
\begin{aligned}
& \text { Fat }(14 \mathrm{~g}) \times 37.7 \mathrm{~kJ} / \mathrm{g}+(8 \mathrm{~g} \text { total carbohydrate } \\
& \quad-3 \mathrm{~g} \text { total dietary fibre }) \times 16.7 \mathrm{~kJ} / \mathrm{g}+6 \mathrm{~g} \text { protein } \times 16.7 \mathrm{~kJ} / \mathrm{g} \\
& =711 \mathrm{~kJ} .
\end{aligned}
$$

A $30 \mathrm{~g}$ serving of pistachios provides $14 \mathrm{~g}$ fat, $8 \mathrm{~g}$ total carbohydrate (including $3 \mathrm{~g}$ total dietary fibre) and $6 \mathrm{~g}$ protein. Note that current US Food and Drug Administration regulations allow insoluble fibre to be assigned an energy density of zero, thus the contribution of fibre has been subtracted from the total carbohydrate in the equation given later. Based on this information, the calculated energy density of pistachios is $711 \mathrm{~kJ} / 30 \mathrm{~g}$, yielding an energy density of $23.7 \mathrm{~kJ} / \mathrm{g}$.

\section{Statistical analysis}

To determine the effect of the treatment on wet weight, dry weight, number of bowel movements and chemical composition of the diet and excreta, we performed a mixed-model repeated-measures ANOVA using the subject as the random term (SAS version 9; SAS Institute, Inc., Cary, NC, USA). The statistical model included terms for treatment and period and interaction terms for subject $\times$ treatment. Results are reported as least-square means and SEM.

\section{Results}

Of the eighteen subjects who began the study, sixteen completed the entire study protocol. Two subjects failed to complete the study due to schedule conflicts. Physical characteristics of the sixteen subjects are reported in Table 1. There were no self-reported side effects of the treatment. No major compliance issues were detected.

The food intake (dry weight) and $\mathrm{N}$ intake did not differ among treatments (Table 2). With the addition of pistachios and concomitant reduction of the base diet, there was an increase in the daily intake of fat and total dietary fibre with a concomitant reduction in total carbohydrate. These changes were significant between the control and $1.5 \mathrm{oz} / \mathrm{d}$ treatments as well as between the $1.5 \mathrm{oz} / \mathrm{d}$ and the $3 \mathrm{oz} / \mathrm{d}$ treatments. There was a small increase in GEI between the control and $3 \mathrm{oz} / \mathrm{d}$ treatments $(452 \mathrm{~kJ} / \mathrm{d})$, whereas the energy intake of the $1.5 \mathrm{oz} / \mathrm{d}$ treatment was intermediate to the two other treatments and not different from either of the other treatments.

Total faecal wet weight increased from the control to the $1.5 \mathrm{oz} / \mathrm{d}$ treatment and was not different for the $1.5 \mathrm{oz} / \mathrm{d}$ compared with the $3 \mathrm{oz} / \mathrm{d}$ treatment (Table 3 ). Faecal dry weight increased from the control to the $1.5 \mathrm{oz} / \mathrm{d}$ treatment and further increased from the $1.5 \mathrm{oz} / \mathrm{d}$ to the $3 \mathrm{oz} / \mathrm{d}$ treatment. Faecal fat increased from the control to the $1.5 \mathrm{oz} / \mathrm{d}$ treatment and did not further increase from the $1.5 \mathrm{oz} / \mathrm{d}$ to the $3 \mathrm{oz} / \mathrm{d}$ treatment. Faecal energy output increased from the control to the $1.5 \mathrm{oz} / \mathrm{d}$ treatment and further increased from the $1.5 \mathrm{oz} / \mathrm{d}$ to the $3 \mathrm{oz} / \mathrm{d}$ treatment. Faecal total carbohydrate and total dietary fibre were similar among treatments. There was no effect of treatment on the number of bowel movements during the $7-\mathrm{d}$ collection period.

The digestibility of fat and energy decreased with the addition of pistachios to the diet (Table 4). The dose size of pistachios did not affect digestibility of fat or energy, as these values were similar between the 1.5 and $3 \mathrm{oz} / \mathrm{d}$ treatments. Total dietary fibre digestibility increased with the addition of

\begin{tabular}{|c|c|c|c|c|c|}
\hline & \multicolumn{3}{|c|}{ Treatment } & \multirow[b]{3}{*}{ SE } & \multirow{3}{*}{$\frac{\text { Treatment effect }}{P}$} \\
\hline & Control & $1.5 \mathrm{oz} / \mathrm{d}$ & $3.0 \mathrm{oz} / \mathrm{d}$ & & \\
\hline & Mean & Mean & Mean & & \\
\hline Dry weight $(g / d)$ & 528 & 521 & 514 & 21 & 0.1055 \\
\hline Fat $(\mathrm{g} / \mathrm{d})$ & $73.8^{a}$ & $86 \cdot 6^{\mathrm{b}}$ & $99 \cdot 3^{\mathrm{c}}$ & 3.1 & $<0.0001$ \\
\hline Total carbohydrate $(\mathrm{g} / \mathrm{d})$ & $337 \cdot 0^{\mathrm{a}}$ & $316.9^{\mathrm{b}}$ & $296 \cdot 3^{c}$ & 14 & $<0.0001$ \\
\hline Total dietary fibre $(\mathrm{g} / \mathrm{d})$ & $32 \cdot 7^{\mathrm{a}}$ & $35 \cdot 2^{\mathrm{b}}$ & $37 \cdot 6^{\mathrm{C}}$ & 1.3 & $<0.0001$ \\
\hline$N(g / d)$ & 16 & 16 & 16 & 0.6 & 0.1285 \\
\hline Energy (kJ/d) & $10780^{a}$ & $11010^{\mathrm{a}, \mathrm{b}}$ & $11230^{\mathrm{b}}$ & 430 & 0.0194 \\
\hline
\end{tabular}

Table 2. Daily nutrient and energy intake

(Mean values with their standard errors)

a,b,c Mean values within a row with unlike superscript letters were significantly different. 
Table 3. Bowel movements and faecal composition

(Mean values with their standard errors)

\begin{tabular}{|c|c|c|c|c|c|}
\hline & \multicolumn{3}{|c|}{ Treatment } & \multirow[b]{3}{*}{ SE } & \multirow{3}{*}{$\frac{\text { Treatment effect }}{P}$} \\
\hline & Control & $1.5 \mathrm{oz} / \mathrm{d}$ & $3.0 \mathrm{oz} / \mathrm{d}$ & & \\
\hline & Mean & Mean & Mean & & \\
\hline Bowel movements $(n / \mathrm{d})$ & $1 \cdot 1$ & $1 \cdot 1$ & 1.2 & 0.1 & 0.4424 \\
\hline Wet weight $(g / d)$ & $114 \cdot 8^{\mathrm{a}}$ & $122 \cdot 9^{\mathrm{b}}$ & $141 \cdot 8^{b}$ & $11 \cdot 1$ & 0.0100 \\
\hline Dry weight $(\mathrm{g} / \mathrm{d})$ & $28 \cdot 7^{\mathrm{a}}$ & $33 \cdot 6^{\mathrm{b}}$ & $38.5^{\mathrm{c}}$ & $2 \cdot 3$ & 0.0001 \\
\hline Fat $(\mathrm{g} / \mathrm{d})$ & $2 \cdot 0^{\mathrm{a}}$ & $6 \cdot 7^{\mathrm{b}}$ & $8 \cdot 7^{\mathrm{b}}$ & 0.8 & $<0.0001$ \\
\hline Total carbohydrate $(\mathrm{g} / \mathrm{d})$ & $13 \cdot 0$ & $12 \cdot 0$ & $13 \cdot 9$ & $1 \cdot 1$ & 0.1643 \\
\hline Total dietary fibre $(\mathrm{g} / \mathrm{d})$ & 9.5 & $9 \cdot 0$ & 9.3 & 0.9 & 0.6316 \\
\hline Energy $(\mathrm{kJ} / \mathrm{d})$ & $546 \cdot 8^{\mathrm{a}}$ & $759 \cdot 4^{\mathrm{b}}$ & $923 \cdot 4^{\mathrm{c}}$ & $55 \cdot 6$ & $<0.0001$ \\
\hline
\end{tabular}

a,b,c Mean values within a row with unlike superscript letters were significantly different.

pistachios, and the increase was significant for the $3 \mathrm{oz} / \mathrm{d}$ treatment compared to the control. The $1.5 \mathrm{oz} / \mathrm{d}$ treatment was intermediate to the control and $3 \mathrm{oz} / \mathrm{d}$ treatment.

Based on the measurements collected in this study, the ME value of pistachios is calculated to be $22.6 \mathrm{~kJ} / \mathrm{g}$. This is lower than the value of $23.7 \mathrm{~kJ} / \mathrm{g}$ as calculated by the Atwater general factors. Among individuals, there was a range in the measured ME value of pistachios from 12.6 to $27 \cdot 3 \mathrm{~kJ} / \mathrm{g}$.

There was no effect of treatment on plasma total cholesterol, HDL-cholesterol or TAG. Plasma LDL-cholesterol level after consumption of the control diet, $1.5 \mathrm{oz} / \mathrm{d}$ treatment, and the $3 \mathrm{oz} / \mathrm{d}$ treatment was 1313 (SEM 22), 1239 (SEM 22) and 1234 (SEM 21) $\mathrm{mg} / \mathrm{l}$, respectively. Plasma LDLcholesterol concentration was $6 \%$ lower after the 1.5 and $3 \mathrm{oz} / \mathrm{d}$ treatment albeit there was no additional reduction in LDL-cholesterol from the 1.5 to the $3 \mathrm{oz} / \mathrm{d}$ treatment.

\section{Discussion}

Nuts in general, and pistachios in particular, have been associated with various health benefits. Hypercholesterolaemic adults consuming a diet containing $2-3$ oz pistachios daily showed improvement in lipid profiles ${ }^{(29)}$. In another study, two servings of pistachios per day resulted in lowering of total cholesterol, LDL-cholesterol, plasma stearoyl-CoA desaturase activity and other biomarkers of $\mathrm{CVD}^{(8)}$. Pistachios have also been shown to improve blood glucose concentrations, endothelial function and indices of inflammation ${ }^{(14)}$. Thus, inclusion of pistachios in the diet has beneficial influences on health, and accurate information about the energy density of pistachios is important for consumers to make educated decisions about incorporation of pistachios into the diet.

We have measured gross energy of pistachio nuts to be $29 \cdot 46 \mathrm{~kJ} / \mathrm{g}$. The results of this study support our hypothesis that the ME content of pistachios is less than that calculated by the Atwater general factors. The measured ME density of pistachios is $22.6 \mathrm{~kJ} / \mathrm{g}$. This value is $5 \%$ less than the currently accepted energy value of $23.7 \mathrm{~kJ} / \mathrm{g}$, as calculated using the Atwater general factors (yet neglecting the contribution of fibre, according to current US Food and Drug Administration regulations) and as reflected currently on nutrient labels. Therefore, based on the measured ME of pistachios, $1 \mathrm{oz}$ serving $(28 \mathrm{~g}$ ) provides $633 \mathrm{~kJ}$, and a $30 \mathrm{~g}$ serving (as is currently used for many pistachio labels) provides $678 \mathrm{~kJ}$. The current method for calculating energy content based on Atwater general factors results in an energy content of $668.6 \mathrm{~kJ}$ for a $28 \mathrm{~g}$ serving and $711.3 \mathrm{~kJ}$ for a $30 \mathrm{~g}$ serving. If the Atwater method was performed with the estimated energy content of fibre being $8.4 \mathrm{~kJ} / \mathrm{g}$ (the expected energy content of fibre), then the $28 \mathrm{~g}$ serving would provide $689.5 \mathrm{~kJ}$ and the $30 \mathrm{~g}$ serving would provide $736.4 \mathrm{~kJ}$. These values are summarised in Table 5. Labelling regulations permit the assignment of a value of $0 \mathrm{~kJ} / \mathrm{g}$ for insoluble fibre even though the energy value of insoluble fibre is likely approximately $8.4-12.6 \mathrm{~kJ} / \mathrm{g}$. If the Atwater calculation included the energy contribution of fibre, the label value for the energy content of a $30 \mathrm{~g}$ serving would be $736-749 \mathrm{~kJ}$.

Table 4. Nutrient and energy digestibility

(Mean values with their standard errors)

\begin{tabular}{|c|c|c|c|c|c|}
\hline & \multicolumn{3}{|c|}{ Treatment } & & \multirow[b]{2}{*}{ Treatment effect } \\
\hline & Control & $1.5 \mathrm{oz} / \mathrm{d}$ & $3.0 \mathrm{oz} / \mathrm{d}$ & & \\
\hline & Mean & Mean & Mean & SE & $P$ \\
\hline Fat (\%) & $97 \cdot 3^{\mathrm{a}}$ & $92 \cdot 4^{\mathrm{b}}$ & $91 \cdot 5^{\mathrm{b}}$ & 0.7 & $<0.0001$ \\
\hline Energy (\%) & $89 \cdot 5^{\mathrm{a}}$ & $87 \cdot 4^{\mathrm{b}}$ & $86 \cdot 8^{\mathrm{b}}$ & 0.4 & 0.0002 \\
\hline Total carbohydrate (\%) & $96 \cdot 1^{a}$ & $96 \cdot 1^{a}$ & $95 \cdot 2^{\mathrm{b}}$ & 0.3 & 0.0066 \\
\hline Total dietary fibre (\%) & $70 \cdot 9^{a}$ & $74 \cdot 3^{a, b}$ & $75 \cdot 6^{\mathrm{b}}$ & $2 \cdot 3$ & 0.0310 \\
\hline
\end{tabular}

a,b Mean values within a row with unlike superscript letters were significantly different. 
Table 5. Energy content $(\mathrm{kJ})$ of a serving of pistachios determined by different methods

\begin{tabular}{lcc}
\hline & 28g serving & 30 g serving \\
\hline $\begin{array}{l}\text { Calculated (Atwater) energy content } \\
\text { assuming fibre energy contribution }\end{array}$ & 669 & 711 \\
is zero & & \\
$\begin{array}{l}\text { Calculated (Atwater) energy content } \\
\text { assuming fibre energy density } \\
\text { is } 8.37 \mathrm{~kJ} / \mathrm{g}\end{array}$ & 690 & 736 \\
$\begin{array}{l}\text { Measured energy content } \\
\text { (present study) }\end{array}$ & 633 & 678 \\
\hline
\end{tabular}

There was a notable inter-individual variability in the ME values of the subjects studied. There are several factors that likely contribute to the variability including individual uniqueness of the microbial population of the gastrointestinal tract, differences in transit time through the gastrointestinal tract and differences in mastication habits. The degree of mastication has been shown to affect lipid accessibility from nuts ${ }^{(30)}$.

Several previous studies have shown that fat from nuts or peanuts is resistant to absorption. As early as 1980, Levine \& Silvis ${ }^{(24)}$ showed that dietary fat excretion was significantly greater after consumption of whole peanuts compared with peanut butter or peanut oil, and this result was confirmed by Traoret et al. ${ }^{(26)}$. Postprandial lipaemia as assessed by plasma TAG was lower after volunteers consumed intact almond seeds compared with almond oil and defatted almond seed starch ${ }^{(25)}$. Mechanical disruption of the almond seed by different levels of controlled chewing influenced fat appearance in faeces, with increased mastication resulting in less faecal fat content ${ }^{(30)}$

Ellis et $a l^{(31)}$ investigated the digestibility of almonds, including the effects of mechanical disruption, chewing and digestion on almond seed microstructure and intracellular lipid release. Inspection of faecal samples from adults consuming almonds revealed intact cotyledon cells (embryonic tissue within the seed of a plant), such that intracellular lipid was encapsulated within the cell walls, protecting it from digestion and absorption. Mechanical disruption (such as chewing) of almond tissue ruptured only cells at the fractured surface layer, leaving cells in deeper layers intact.

The effect on LDL-cholesterol from pistachios added to the diet is consistent with recent published pistachio research and research with other tree nuts. Previously published interventions have resulted in an increase in HDL-cholesterol with tree nut consumption, and the inability to detect an effect on HDL-cholesterol in this study is likely due to the fact that this study was not powered to detect a change in HDLcholesterol (the effect of pistachios on lipid measurements were conducted opportunistically and not as a primary outcome of this study).

Since this study was conducted in a free-living population, it is possible that subjects might have consumed foods that were not part of the controlled diet. Such non-compliance could add error to the measures. We minimised the probability of non-compliance by observing the consumption of most meals. Nuts were provided at breakfast and dinner so their consumption could be observed as well.

In conclusion, pistachio nuts contain less ME than that calculated from the Atwater general factors. Consumers rely on accurate food labels for making informed dietary choices. Accurate information about ME content of foods is important for reliable food labelling.

\section{Acknowledgements}

This work was supported by the US Department of Agriculture, ARS and Paramount Farms, Inc. The authors have no conflicts of interest to report. Author contributions were as follows: D. J. B. and J. A. N. designed the study; D. J. B., J. A. N. and S. K. G. conducted the study and analysed the data and D. J. B. and J. A. N. interpreted data and wrote the manuscript.

\section{References}

1. World Health Organization (2003) Obesity and Overweight. Global Strategy on Diet, Physical Activity, and Health. Geneva: WHO.

2. World Health Organization (2003) Diet, Nutrition, and the Prevention of Chronic Diseases. WHO Technical Report Series. Geneva: WHO.

3. Rolls BJ, Drewnowski A \& Ledikwe JH (2005) Changing the energy density of the diet as a strategy for weight management. J Am Diet Assoc 105, S98-S103.

4. Rolls BJ (2009) The relationship between dietary energy density and energy intake. Physiol Behav 97, 609-615.

5. James WP (2008) WHO recognition of the global obesity epidemic. Int J Obes (London) 32, Suppl. 7, S120-S126.

6. Sabate J, Haddad E, Tanzman JS, et al. (2003) Serum lipid response to the graduated enrichment of a Step I diet with almonds: a randomized feeding trial. Am J Clin Nutr 77, $1379-1384$

7. Griel AE \& Kris-Etherton PM (2006) Tree nuts and the lipid profile: a review of clinical studies. Br J Nutr 96, Suppl. 2, S68-S78.

8. Gebauer SK, West SG, Kay CD, et al. (2008) Effects of pistachios on cardiovascular disease risk factors and potential mechanisms of action: a dose-response study. Am J Clin Nutr 88, 651-659.

9. Fraser GE, Sabate J, Beeson WL, et al. (1992) A possible protective effect of nut consumption on risk of coronary heart disease. The Adventist Health Study. Arch Intern Med 152, $1416-1424$.

10. Hu FB, Stampfer MJ, Manson JE, et al. (1998) Frequent nut consumption and risk of coronary heart disease in women: prospective cohort study. BMJ 317, 1341-1345.

11. Josse AR, Kendall CW, Augustin LS, et al. (2007) Almonds and postprandial glycemia - a dose-response study. Metabolism 56, 400-404.

12. Jiang R, Manson JE, Stampfer MJ, et al. (2002) Nut and peanut butter consumption and risk of type 2 diabetes in women. JAMA 288, 2554-2560.

13. Jenkins DJ, Kendall CW, Marchie A, et al. (2008) Effect of almonds on insulin secretion and insulin resistance in nondiabetic hyperlipidemic subjects: a randomized controlled crossover trial. Metabolism 57, 882-887.

14. Sari I, Baltaci Y, Bagci C, et al. (2010) Effect of pistachio diet on lipid parameters, endothelial function, inflammation, and oxidative status: a prospective study. Nutrition 26, 399-404. 
15. Davis PA \& Iwahashi CK (2001) Whole almonds and almond fractions reduce aberrant crypt foci in a rat model of colon carcinogenesis. Cancer Lett 165, 27-33.

16. Gonzalez CA \& Salas-Salvado J (2006) The potential of nuts in the prevention of cancer. BrJ Nutr 96, Suppl. 2, S87-S94.

17. Casas-Agustench P, Bulló M, Ros E, et al. (2010) Crosssectional association of nut intake with adiposity in a Mediterranean population. Nutr Metab Cardiovasc Dis (Epublication ahead of print version 8 March 2010).

18. Morgan WA \& Clayshulte BJ (2000) Pecans lower low-density lipoprotein cholesterol in people with normal lipid levels. J Am Diet Assoc 100, 312-318.

19. Alper CM \& Mattes RD (2002) Effects of chronic peanut consumption on energy balance and hedonics. Int $J$ Obes Relat Metab Disord 26, 1129-1137.

20. Fraser GE, Bennett HW, Jaceldo KB, et al. (2002) Effect on body weight of a free 76 kilojoule ( 320 calorie) daily supplement of almonds for six months. J Am Coll Nutr 21, 275-283.

21. Wien MA, Sabate JM, Ikle DN, et al. (2003) Almonds vs complex carbohydrates in a weight reduction program. Int J Obes Relat Metab Disord 27, 1365-1372.

22. Sabate J, Cordero-Macintyre Z, Siapco G, et al. (2005) Does regular walnut consumption lead to weight gain? Br J Nutr 94, 859-864.

23. Hollis J \& Mattes R (2007) Effect of chronic consumption of almonds on body weight in healthy humans. Br J Nutr $\mathbf{9 8}$, 651-656.
24. Levine AS \& Silvis SE (1980) Absorption of whole peanuts, peanut oil, and peanut butter. $N$ Engl J Med 303 917-918

25. Berry SE, Tydeman EA, Lewis HB, et al. (2008) Manipulation of lipid bioaccessibility of almond seeds influences postprandial lipemia in healthy human subjects. Am J Clin Nutr 88, 922-929.

26. Traoret CJ, Lokko P, Cruz AC, et al. (2008) Peanut digestion and energy balance. Int J Obes (London) 32, 322-328.

27. Casas-Agustench P, Lopez-Uriarte P, Bullo M, et al. (2011) Effects of one serving of mixed nuts on serum lipids, insulin resistance and inflammatory markers in patients with the metabolic syndrome. Nutr Metab Cardiovasc Dis 21, 126-135.

28. Baer DJ, Rumpler WV, Miles CW, et al. (1997) Dietary fiber decreases the metabolizable energy content and nutrient digestibility of mixed diets fed to humans. J Nutr 127, 579-586.

29. Sheridan MJ, Cooper JN, Erario M, et al. (2007) Pistachio nut consumption and serum lipid levels. J Am Coll Nutr 26 , $141-148$

30. Cassady BA, Hollis JH, Fulford AD, et al. (2009) Mastication of almonds: effects of lipid bioaccessibility, appetite, and hormone response. Am J Clin Nutr 89, 794-800.

31. Ellis PR, Kendall CW, Ren Y, et al. (2004) Role of cell walls in the bioaccessibility of lipids in almond seeds. Am J Clin Nutr 80, 604-613. 